\title{
Pharmacotherapies in Heart Failure With Preserved Ejection Fraction: A Systematic Review and Meta-Analysis of Randomized Controlled Trials
}

Nischit Baral ${ }^{1}$, Swotantra Gautam ${ }^{2}$, Saroj A. Yadav ${ }^{3}$, Sangeeta Poudel ${ }^{4}$, Govinda Adhikari ${ }^{5}$, Rohit Rauniyar ${ }^{5}$, Pramod Savarapu ${ }^{5}$, Anjan Katel ${ }^{6}$, Anish C. Paudel ${ }^{7}$, Prem R. Parajuli ${ }^{7}$

1. Internal Medicine, McLaren Health Care, Flint/Michigan State University, Michigan, USA 2. General Medicine, B. P. Koirala Institute of Health Sciences, Dharan, NPL 3. General Medicine, Patan Academy of Health Sciences, Kathmandu, NPL 4. General Medicine, KIST Medical College/Tribhuvan University, Kathmandu, NPL 5. Internal Medicine, McLaren Flint/Michigan State University, Flint, USA 6. Internal Medicine, Kathmandu University School of Medical Sciences, Dhulikhel, NPL 7. Internal Medicine, Reading Hospital Tower Health, Reading, USA

Corresponding author: Nischit Baral, nischit.baral@mclaren.org

\begin{abstract}
Background: Heart failure (HF) with preserved ejection fraction (HFpEF) causes significant cardiovascular morbidity and mortality. It is a growing problem in the developed world, especially, in the aging population. There is a paucity of data on the treatment of patients with HFpEF. We aimed to identify pharmacotherapies that improve peak oxygen consumption (peak $\mathrm{VO}_{2}$ ), cardiovascular mortality, and HF hospitalizations in patients with HFpEF.
\end{abstract}

Methods: We conducted a systematic literature search for English studies in PubMed, EMBASE, Cochrane Central Register of Controlled Trials, Web of Science, Scopus, and Google scholar. We searched databases using terms relating to or describing HFpEF, stage C HFpEF, and diastolic HF and included only randomized controlled trials (RCTs). RevMan 5.4 (The Cochrane Collaboration, 2020, London, UK) was used for data analysis, and two independent investigators performed literature retrieval and data-extraction. We used PRISMA guidelines to report the outcomes. We included 14 articles in our systematic review and six studies in meta-analysis.

Results: We calculated the pooled mean difference (MD) of peak $\mathrm{VO}_{2}$ between placebo and pharmacotherapies. Our meta-analysis showed that the peak $\mathrm{VO}_{2}$ was comparable between pharmacotherapies and placebo in HFpEF (MD = 0.09, 95\% CI: $-0.11,0.30, \mathrm{I}^{2}=28 \%$ ). Our systematic review highlights that statins and spironolactone use should be further studied in larger RCTs due to their potential beneficial effect on all-cause mortality and hospitalizations, respectively.

Review began 02/18/2021 Review ended 02/20/2021 Published 02/28/2021

๑) Copyright 2021 Baral et al. This is an open access article distributed under the terms of the Creative Commons Attribution License CC-BY 4.0., which permits unrestricted use, distribution, and reproduction in any medium, provided the original author and source are credited.
Conclusion: Compared to placebo, none of the pharmacotherapies significantly improved peak VO2 in $\mathrm{HFpEF}$ except ivabradine. In our meta-analysis, the pooled improvement in peak $\mathrm{VO}_{2}$ is non-significant. This needs validation with larger studies. We are lacking larger studies on pharmacotherapies that improve peak $\mathrm{VO}_{2}$ in HFpEF. Statin and spironolactone should be further studied in patients with HFpEF as few trials have shown improvement in all-cause mortality and reduction in HF hospitalizations in selected patients, respectively.

Categories: Cardiology, Internal Medicine, Medical Education

Keywords: all-cause mortality, pharmacotherapies, heart failure, heart failure with preserved ejection fraction, peak vo2, cardiovascular mortality, hospitalization

\section{Introduction}

More than 6.2 million adults in the United States suffer from heart failure (HF) [1]. HF with preserved ejection fraction (HFpEF) composes half of all patients with HF [2]. Patients with HFpEF are more likely to be older, female, and have multiple co-morbid conditions, and no drugs have yet been shown to improve morbidity and mortality [3]. Symptom burden and adverse outcomes of HFpEF are similar to patients with HF with a reduced ejection fraction (HFrEF) [4]. American College of Cardiology/American Heart Association 2017 Guidelines recommend management of HFpEF by treating the contributing factors and comorbidities that are frequently present and significantly impact the clinical course. The most common include hypertension, lung disease, coronary artery disease, obesity, anemia, diabetes mellitus, kidney disease, and sleep-disordered breathing [5]. There is a paucity of data on newer pharmacotherapies in HFpEF. The aim of this analysis was to identify pharmacotherapies that improve peak oxygen consumption (peak $\mathrm{VO}_{2}$ ), cardiovascular mortality, and HF hospitalizations in patients with HFpEF.

\section{Materials And Methods}

\section{Search strategy}

A comprehensive literature search was performed on PubMed, Cochrane database, Embase, Google Scholar, and Web of Science identifying using relevant Medical Subject Headings (MeSH) and key word termed HFpEF (Heart Failure with Preserved Ejection Fraction) or HFnEF (Heart Failure with Normal Ejection Fraction) and "management," "pharmacotherapy," "future therapy," "Neprilysin 


\section{Cureus}

inhibitor,” “sacubitril,” “valsaltran,” “Interleukin-1 Blocker,” “anakinra,” “Phosphodiesterase-5

inhibitor," "sildenafil,” "If-channel inhibitor," "Ivabradine,” “endothelin type A receptor

antagonist," "sitaxsentan," "inhaled $\beta$-adrenergic

agonist," "albuterol," “metformin," "luseogliflozin," "voglibose," "Ranolazine," “statins," “digoxin,” "Neladenoson,” "Erythropoiet "L-arginine L-citrulline," “Serelaxin,” "Spironolactone,” “aldosterone antagonist,” and "CoQ” with additional filters of human studies and customized articles in accordance with Preferred Reporting Items for Systematic Reviews and Meta-analysis (PRISMA) guidelines [6]. A staged literature search was performed. All identified articles reference lists were analyzed for additional studies through further snowball sampling. All relevant articles were screened and only appropriate articles included after full-text analysis.

\section{Inclusion and exclusion criteria}

We included human studies on patients with diagnosed HFpEF based on an ejection fraction more than or equal to $45 \%$ and discussing management of HFpEF for full-text analysis. We excluded editorials, consensus documents, commentaries, review articles, and case reports. We excluded studies with an ejection fraction less than $45 \%$.

\section{Data extraction}

All articles were screened by two authors and any disagreement was reached by consensus or involvement of a third author. Data were extracted by two authors and validated by a third author.

Risk of Bias Assessment

Cochrane Collaboration risk of bias tool was used to assess the risk of bias. The quality of included studies was assessed by two authors with the help of the Cochrane Risk of Bias assessment tool. The risk of bias of the included studies was graded as low in the following aspects: random sequence generation, allocation concealment, blinding of participants and personnel, incomplete outcome data, selective reporting, and other biases. The risk of bias in the blinding of outcome assessment was graded as high (Figure 1).

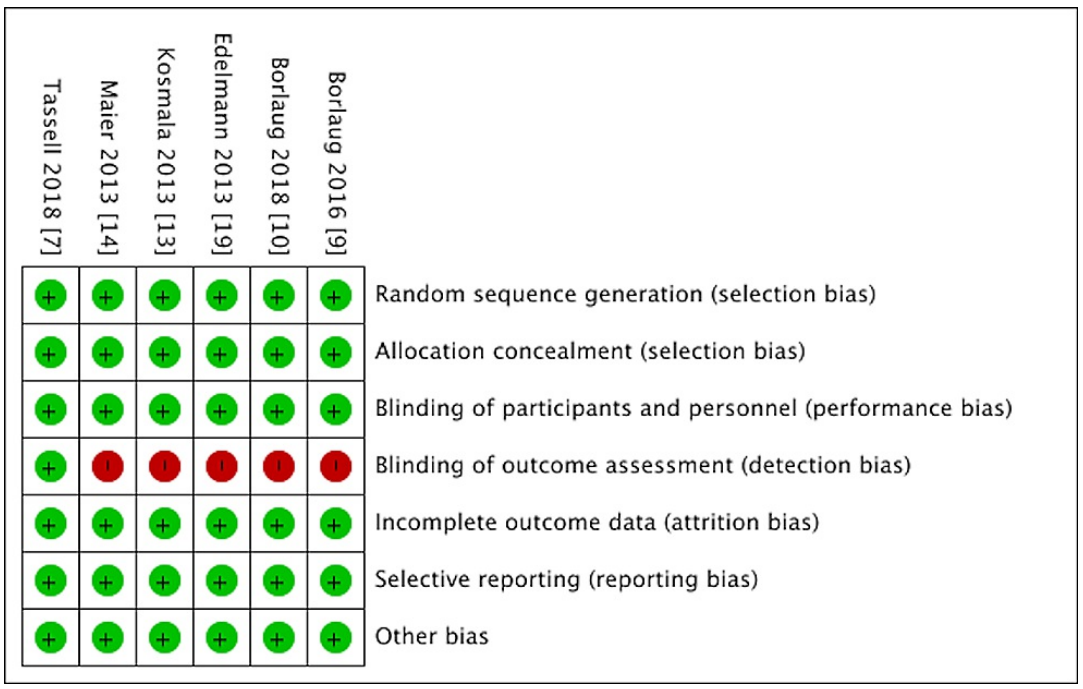

FIGURE 1: Cochrane Risk of Bias tool showing the risk of bias in included randomized controlled trials

\section{Results}

\section{Studies included}

The search using the appropriate terms in January 2021 yielded 1225 potentially relevant articles. In addition, 41 potential articles were included through Web of Science, Embase.com, and Review of references. We included only 14 articles randomizing 6370 participates for 10 different pharmacotherapies according to the homogeneity of these studies with our inclusion criteria (Figure 2). 


\section{Cureus}

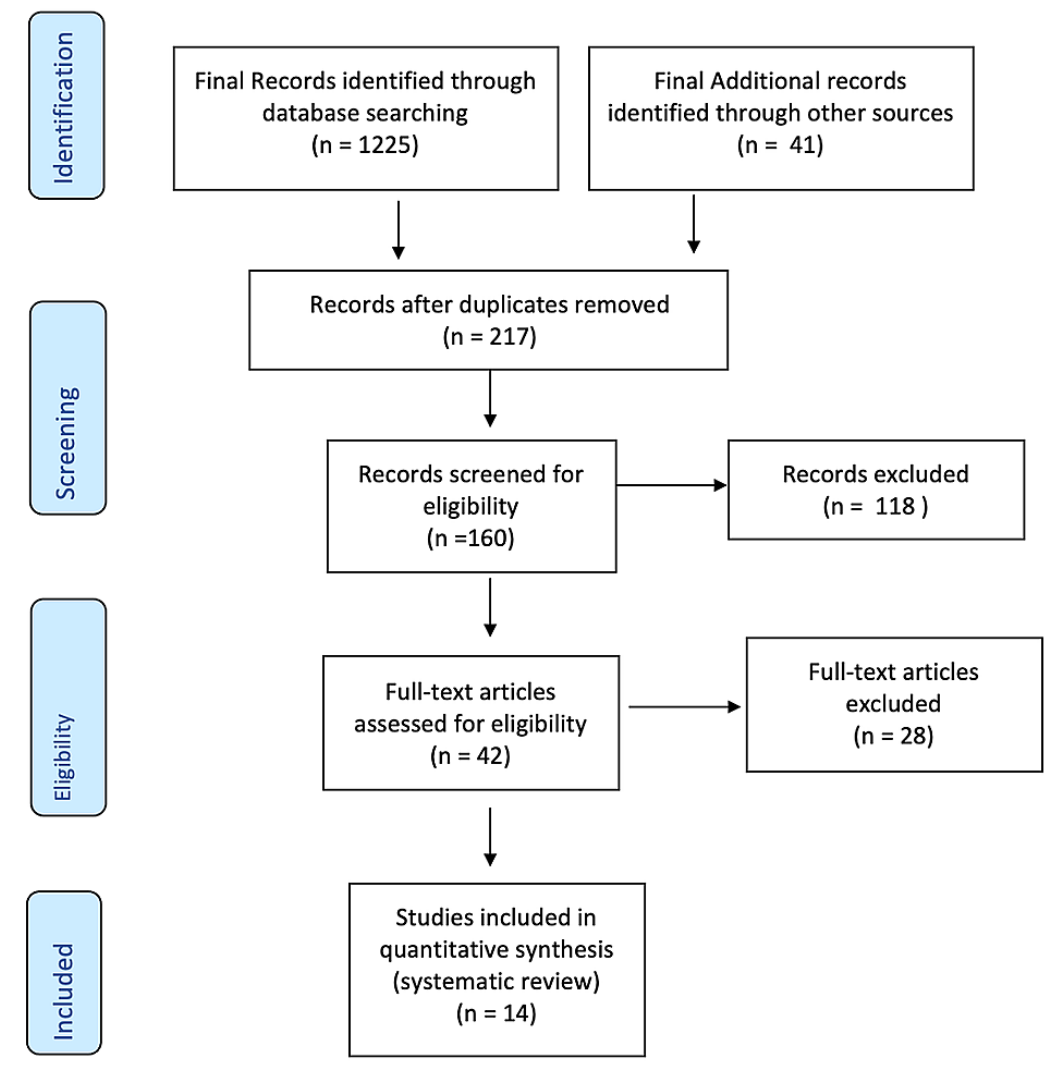

FIGURE 2: PRISMA flow diagram of included studies

PRISMA: preferred reporting items for systematic reviews and meta-analysis

\section{Outcomes}

Characteristics of Included Studies

We included six of the RCTs commenting on peak $\mathrm{VO}_{2}$ for the meta-analysis comparing pharmacotherapies with placebo. The rest of the RCTs did not comment on peak VO2 (Table 1).

\begin{tabular}{|c|c|c|c|c|c|c|c|}
\hline \multirow[b]{2}{*}{ S.N. } & \multirow{2}{*}{$\begin{array}{l}\text { Study drug } \\
\text { and trial }\end{array}$} & \multirow{2}{*}{$\begin{array}{l}\text { Type of } \\
\text { study }\end{array}$} & \multirow[b]{2}{*}{ Inclusion criteria } & \multirow{2}{*}{$\begin{array}{l}\text { Sample } \\
\text { size }\end{array}$} & \multicolumn{3}{|l|}{ Outcome: Improvement seen in } \\
\hline & & & & & Mortality benefits & $\begin{array}{l}\text { Hemodynamics } \\
\text { and biomarkers }\end{array}$ & $\begin{array}{l}\text { peak VO }{ }_{2} \text {, } \\
6 \mathrm{MWD}, \mathrm{QoL}\end{array}$ \\
\hline 1 & $\begin{array}{l}\text { Anakinra } \\
\text { DHART } 2 \\
\text { trial [7] }\end{array}$ & $\begin{array}{l}\text { Double- } \\
\text { blind, } \\
\text { placebo- } \\
\text { controlled } \\
\text { RCT }\end{array}$ & LVEF $\geq 50 \%$ NYHA class II-III & $\mathrm{N}=31$ & 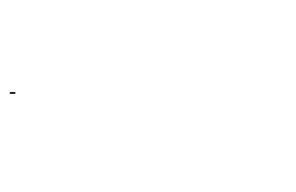 & $\begin{array}{l}\text { Reduction in } \\
\text { CRP and NT- } \\
\text { proBNP }\end{array}$ & $\begin{array}{l}\text { No } \\
\text { improvement } \\
\text { is seen. } \\
\text { No significant } \\
\text { improvement } \\
\text { in peak } \mathrm{VO}_{2} \text {. }\end{array}$ \\
\hline 2 & $\begin{array}{l}\text { Sildenafil } \\
\text { RELAX trial [8] }\end{array}$ & $\begin{array}{l}\text { Multicenter, } \\
\text { double-blind, } \\
\text { parallel- } \\
\text { group RCT }\end{array}$ & LVEF $\geq 50 \%$ & $\mathrm{~N}=216$ & - & - & $\begin{array}{l}\text { No } \\
\text { improvement } \\
\text { was seen in } \\
\text { peak } \mathrm{VO}_{2} \text { and } \\
6 \mathrm{MWD} \text {. }\end{array}$ \\
\hline 3 & $\begin{array}{l}\text { Nebulized } \\
\text { inhaled sodium } \\
\text { nitrite [9] }\end{array}$ & $\begin{array}{l}\text { Single- } \\
\text { center, } \\
\text { double-blind, } \\
\text { parallel- } \\
\text { group RCT }\end{array}$ & LVEF $\geq 50 \%$ & $\mathrm{~N}=26$ & Not available & $\begin{array}{l}\text { No any } \\
\text { improvement in } \\
\text { CO or stroke } \\
\text { volume }\end{array}$ & $\begin{array}{l}\text { Reduces } \\
\text { PCWP, } \\
\text { biventricular } \\
\text { filling } \\
\text { pressure, and } \\
\text { pulmonary } \\
\text { artery }\end{array}$ \\
\hline
\end{tabular}




\section{Cureus}

\begin{tabular}{|c|c|c|c|c|c|c|c|}
\hline & \multirow[b]{2}{*}{$\begin{array}{l}\text { pressure. } \\
\text { No } \\
\text { improvement } \\
\text { was seen in } \\
\text { peak } \mathrm{VO}_{2} \text { after } \\
\text { treatment for } \\
\text { four weeks. }\end{array}$} \\
\hline 4 & $\begin{array}{l}\text { Inorganic } \\
\text { nitrite INDIE- } \\
\text { HFpEF } \\
\text { trial [10] }\end{array}$ & $\begin{array}{l}\text { Multicenter, } \\
\text { double-blind, } \\
\text { placebo- } \\
\text { controlled, 2- } \\
\text { treatment, } \\
\text { crossover } \\
\text { trial }\end{array}$ & LVEF $\geq 50 \%$ & $N=105$ & - & - & \\
\hline 5 & $\begin{array}{l}\text { Statin (CHART- } \\
\text { 2) [11] }\end{array}$ & $\begin{array}{l}\text { An } \\
\text { observational } \\
\text { study from } \\
\text { Japanese } \\
\text { registry }\end{array}$ & LVEF $\geq 50 \%$ & $\mathrm{~N}=4544$ & $\begin{array}{l}\text { Reduced incidence of all-cause } \\
\text { death, non-cardiovascular death, } \\
\text { and sudden death. }\end{array}$ & & $\begin{array}{l}\text { Not measured } \\
\text { in the trial }\end{array}$ \\
\hline 6 & $\begin{array}{l}\text { Digoxin DIG } \\
\text { trial [12] }\end{array}$ & $\begin{array}{l}\text { Subgroup } \\
\text { and } \\
\text { retrospective } \\
\text { analysis from } \\
\text { DIG trial }\end{array}$ & LVEF $\geq 50 \%$ & $\mathrm{~N}=719$ & $\begin{array}{l}\text { No mortality benefit in the } \\
\text { subgroup of HFpEF. }\end{array}$ & & $\begin{array}{l}\text { No } \\
\text { statistically } \\
\text { significant } \\
\text { reduction in } \\
\text { hospitalization } \\
\text { in the HFpEF } \\
\text { subgroup. }\end{array}$ \\
\hline 7 & Ivabradine [13] & & LVEF $\geq 50 \%$ & $\mathrm{~N}=61$ & - & $\begin{array}{l}\text { LV filling } \\
\text { pressure }\end{array}$ & $\begin{array}{l}\text { A significant } \\
\text { change in } \\
\text { exercise } \\
\text { capacity and } \\
\text { peak } \mathrm{VO}_{2} \text {. }\end{array}$ \\
\hline 8 & $\begin{array}{l}\text { Ranolazine } \\
\text { RALI-DHF trial } \\
\text { [14] }\end{array}$ & $\begin{array}{l}\text { Prospective, } \\
\text { double-blind, } \\
\text { placebo- } \\
\text { controlled } \\
\text { RCT }\end{array}$ & LVEF $\geq 45 \%$ & $\mathrm{~N}=20$ & - & $\begin{array}{l}\text { Decrease } \\
\text { LVEDP and } \\
\text { PCWP }\end{array}$ & $\begin{array}{l}\text { No significant } \\
\text { change in } \\
\text { peak } \mathrm{VO}_{2} \text { after } \\
14 \text { days of } \\
\text { Ranolazine. }\end{array}$ \\
\hline 9 & $\begin{array}{l}\text { Sitaxsentan } \\
{[15]}\end{array}$ & $\begin{array}{l}\text { Multicenter, } \\
\text { double-blind, } \\
\text { RCT }\end{array}$ & LVEF $\geq 50 \%$, NHYA class II-III & $\mathrm{N}=192$ & - & - & $\begin{array}{l}\text { Improvement } \\
\text { in treadmill } \\
\text { exercise time } \\
\text { after six } \\
\text { months and } \\
\text { exercise } \\
\text { tolerance }\end{array}$ \\
\hline 10 & $\begin{array}{l}\text { Serelaxin } \\
\text { (RELAX-AHF) } \\
{[16]}\end{array}$ & $\begin{array}{l}\mathrm{RCT} \text {, } \\
\text { multicenter, } \\
\text { double-blind, } \\
\text { placebo- } \\
\text { controlled }\end{array}$ & LVEF $\geq 50 \%$ & $N=281$ & No mortality benefits & - & $\begin{array}{l}\text { Improved } \\
\text { dyspnea }\end{array}$ \\
\hline 12 & $\begin{array}{l}\text { Sacubitril- } \\
\text { valsartan } \\
\text { PARAGON-HF } \\
\text { trial [17] }\end{array}$ & $\begin{array}{l}\text { Prospective, } \\
\text { multicenter, } \\
\text { double-blind, } \\
\text { RCT }\end{array}$ & $\begin{array}{l}\text { LVEF } \geq 45 \% \text {, comparison of ARNI } \\
\text { (Sacubitril-Valsartan) versus ARB } \\
\text { (Valsartan), NYHA II-IV }\end{array}$ & $\mathrm{N}=4822$ & $\begin{array}{l}\text { No mortality benefit and not } \\
\text { significantly lower rate of total } \\
\text { HFpEF hospitalizations. }\end{array}$ & - & $\begin{array}{l}\text { No significant } \\
\text { change in the } \\
\text { quality-of-life } \\
\text { score. }\end{array}$ \\
\hline 13 & $\begin{array}{l}\text { Spironolactone } \\
\text { TOPCAT } \\
\text { trial [18] }\end{array}$ & $\begin{array}{l}\text { International, } \\
\text { multicenter, } \\
\text { double-blind } \\
\text { RCT }\end{array}$ & $\begin{array}{l}\text { LVEF } \geq 45 \% \text {, stage C HFpEF, } \\
\text { hospitalization within } 12 \text { months or } \\
\text { elevated BNP/NTpro-BNP. } \\
\text { Exclusion: uncontrolled HTN, serum } \\
\text { potassium }>5.0 \mathrm{mmol} / \mathrm{L} \text {, creatinine } \\
>2.5 \mathrm{mg} / \mathrm{dl} \text {, or eGFR }<30 \mathrm{~mL} / \mathrm{min} \text { per } \\
1.73 \mathrm{~m}^{2} \text {. }\end{array}$ & $\mathrm{N}=3445$ & $\begin{array}{l}\text { No change in the primary } \\
\text { composite outcome event } \\
\text { (cardiovascular mortality, aborted } \\
\text { cardiac arrest, or hospitalizations } \\
\text { for HF) rate. The only reduction in } \\
\text { the HF hospitalization rate in the } \\
\text { treatment group. }\end{array}$ & - & $\begin{array}{l}\text { Did not } \\
\text { comment on } \\
\text { peak } \mathrm{VO}_{2} \text { or } \\
\text { quality of life. }\end{array}$ \\
\hline 14 & $\begin{array}{l}\text { Spironolactone } \\
\text { ALDO-DHF } \\
\text { trial [19] }\end{array}$ & $\begin{array}{l}\text { Prospective, } \\
\text { multicenter, } \\
\text { double-blind } \\
\text { RCT }\end{array}$ & LVEF $\geq 50 \%$, NYHA class II-III & $\mathrm{N}=422$ & No change in hospitalizations. & $\begin{array}{l}\text { Modestly } \\
\text { increased } \\
\text { serum } \\
\text { potassium and } \\
\text { decreased } \\
\text { eGFR. }\end{array}$ & $\begin{array}{l}\text { No change in } \\
\text { peak } \mathrm{VO}_{2} \text { and } \\
\text { quality of life. } \\
\text { Slightly } \\
\text { reduced } \\
\text { 6MWD. }\end{array}$ \\
\hline
\end{tabular}

\section{TABLE 1: Characteristics of Included Studies}

6MWD: six-minute walk distance, peak $\mathrm{VO}_{2}$ : peak oxygen consumption, QoL: quality of life, NYHA: New York Heart Association, LVEF: left ventricular ejection fraction, RCT: randomized controlled trial, N: number of participants, HFpEF: heart failure with preserved ejection fraction, eGFR: estimated glomerular filtration rate, PCWP: pulmonary capillary wedge pressure, LVEDP: left ventricular end-diastolic pressure, DIG: digitalis investigation group, DHART-2: diastolic heart failure Anakinra response trial 2, CHART-2: congestive heart failure cardiopoietic regenerative therapy, 
Change in Peak $\mathrm{VO}_{2}$ among the RCTs: the pooled results from six studies showed that the mean difference in peak $\mathrm{VO}_{2}$ between pharmacotherapies versus placebo was $0.09,95 \% \mathrm{CI}:-0.11,0.30, \mathrm{I} 2=28 \%$. This shows that the mean difference of peak $\mathrm{VO}_{2}$ between the two groups is comparable (Figure 3).

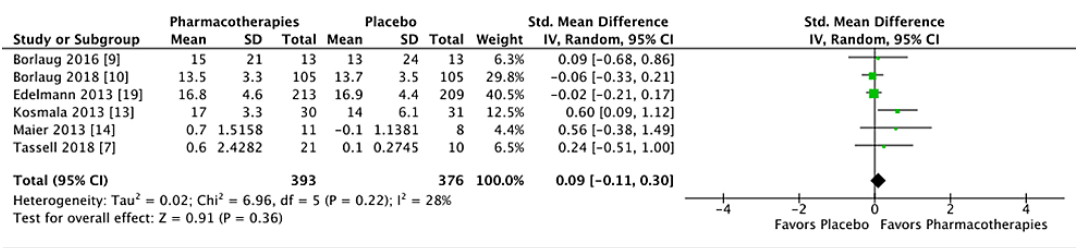

FIGURE 3: Forest plot showing a change in peak oxygen consumption between pharmacotherapies versus placebo

\section{Discussion}

\section{Pharmacotherapies showing improvement of peak $\mathrm{VO}_{2}$}

In our study, the pooled increase in peak $\mathrm{VO}_{2}$ of $0.09 \mathrm{ml} / \mathrm{kg} / \mathrm{min}$ is not statistically significant. Peak $\mathrm{VO}_{2}$ is an objective parameter for cardiorespiratory fitness. In a study by Mancini et al., the increase in peak $\mathrm{VO}_{2}$ from $10 \mathrm{ml} / \mathrm{kg} / \mathrm{min}$ to $14 \mathrm{ml} / \mathrm{kg} / \mathrm{min}$ in $\mathrm{HF}$ patients was associated with a high increase in cumulative survival [20]. In a recent study on inspiratory muscle training in HFpEF, inspiratory muscle training was associated with an increase in peak $\mathrm{VO}_{2}$ and six minutes walk distance [21]. In our study, the change in peak $\mathrm{VO}_{2}$ with pharmacotherapies is comparable with placebo.

\section{Pharmacotherapies showing a mortality benefit}

Out of the 14 included RCTs, only six RCTs or post-hoc of RCTs compared the all-cause mortality with placebo in HFpEF. In CHART-2 trial, the incidence of three-year mortality was lower in statin group compared to placebo ( $8.7 \%$ vs $14.5 \%$, HR: $0.74 ; 95 \% \mathrm{CI} ; 0.58,0.94)$ [11]. In the DIG trial, there was a total of 87 deaths in the digoxin group and 89 deaths in the placebo (HR: 1.06 ; $95 \% \mathrm{CI} ; 0.79,1.42$ ) [12]. In RELAXAHF trial, there were total 11 (8.08\%) deaths in serelaxin group and 16 (11.32\%) deaths in placebo group (HR: $0.70 ; 95 \% \mathrm{CI} ; 0.32,1.50$ ) [16]. In the TOPCAT trial, the primary composite event (cardiovascular death, aborted cardiac arrest, or hospitalizations for HF) rate was not significantly reduced. However, only the hospitalization for HF had a statistically significant reduction in the treatment group compared to placebo (HR 0.83 ; 95\% CI; 0.69-0.99) [18,22]. It is clearly evident from the trials that there have been no promising results for mortality benefit or hospitalization except with statin and spironolactone in selected patients with $\mathrm{HFpEF}$ (with $\mathrm{EF} \geqslant 45 \%$, elevated BNP or $\mathrm{HF}$ admission within one year, estimated glomerular filtration rate $>30$ and creatinine $<2.5 \mathrm{mg} / \mathrm{dl}$, potassium $<5.0 \mathrm{mEq} / \mathrm{L}$ ), to decrease

hospitalizations patients [22]. However, no improvement was seen in the quality of life with statin [11]. Another study by Alehagen et al. done from prospective Swedish Heart Failure Registry in 9140 with HFpEF with $\mathrm{EF}$ more than or equal to $50 \%, 3427$ patients were treated with a statin. Statin showed benefits by reducing cardiovascular death (HR: $0.80 ; 95 \% \mathrm{CI} ; 0.72-0.89 ; \mathrm{P}<0.001)$ and composite all-cause mortality or cardiovascular hospitalizations (HR: 0.89; 95\% CI; 0.82-0.96; $\mathrm{P}=0.0003$ ) [23].

\section{Pharmacotherapies showing improvement in hemodynamics}

The study by Kosmala et al. showed improved LV filling pressure and improvement in exercise capacity (metabolic equivalent) when treated with Ivabradine, a selective sinus node inward "funny" (If) channel inhibitor. The study measured these markers only at rest, not during exercise, and the sample size was only 61 [13]. In the RALI-DHF trial with 20 participants, Ranolazine decreased LV end-diastolic pressure and pulmonary capillary wedge pressure [14]. The study by Borlaug et al. showed inhaled sodium nitrite reduces biventricular filling pressures and pulmonary artery pressures at rest and during exercise in HFpEF [9]. In elderly patients with HFpEF, oral nitrate (delivered as beetroot juice) improves exercise capacity, vasodilation, and cardiac output reserve. This study shows inhaled nitrite could be of potential use for exercise and quality of life improvement for HFpEF [24].

\section{Limitations}

In our systematic review and meta-analysis, we found a limited number of studies done on novel pharmacotherapies and our sample size is not large enough to provide sufficient power. Definitions for HFpEF were not standardized. Ten of the 12 studies defined an EF of $\geqslant 50 \%$ as HFpEF, while two of the RCTs defined an EF of $\geqslant 45 \%$ as HFpEF. This varied cutoff used in RCTs to define HFpEF shows a lack of a universal approach in defining HFpEF [5].

\section{Conclusions}

The mortality, morbidity, and economic burden of HFpEF are huge. There are no clear-cut interventions to the date shown to have mortality benefits in such patients. Uniform definitions for the disease and a 
consensus on disease management are lacking. Many new pathophysiological models seem to be promising and can be potential targets for the future. Compared to placebo, none of the pharmacotherapies improved peak $\mathrm{VO}_{2}$ in $\mathrm{HFpEF}$ except ivabradine. This needs validation with larger studies. Statin and spironolactone should be further studied in patients with HFpEF as few trials have shown improvement in all-cause mortality and reduction in HF hospitalizations in selected patients, respectively.

\section{Additional Information}

\section{Disclosures}

Human subjects: All authors have confirmed that this study did not involve human participants or tissue. Animal subjects: All authors have confirmed that this study did not involve animal subjects or tissue. Conflicts of interest: In compliance with the ICMJE uniform disclosure form, all authors declare the following: Payment/services info: All authors have declared that no financial support was received from any organization for the submitted work. Financial relationships: All authors have declared that they have no financial relationships at present or within the previous three years with any organizations that might have an interest in the submitted work. Other relationships: All authors have declared that there are no other relationships or activities that could appear to have influenced the submitted work.

\section{References}

1. Virani SS, Alonso A, Benjamin EJ, et al.: Heart disease and stroke statistics-2020 update: a report from the American Heart Association. Circulation. 2020, 141:139-596. 10.1161/cir.0000000000000757

2. Borlaug BA: The pathophysiology of heart failure with preserved ejection fraction . Nat Rev Cardiol. 2014, 11:507-515. 10.1038/nrcardio.2014.83

3. Shah SJ, Kitzman DW, Borlaug BA, van Heerebeek L, Zile MR, Kass DA, Paulus WJ: Phenotype-specific treatment of heart failure with preserved ejection fraction: a multiorgan roadmap. Circulation. 2016, 134:73-90. 10.1161/circulationaha.116.021884

4. Bhatia RS, Tu JV, Lee DS, et al.: Outcome of heart failure with preserved ejection fraction in a populationbased study. N Engl J Med. 2006, 355:260-269. 10.1056/NEJMoa051530

5. Yancy CW, Jessup M, Bozkurt B, et al.: 2017 ACC/AHA/HFSA focused update of the 2013 ACCF/AHA Guideline for the management of heart failure: a report of the American College of Cardiology/American Heart Association Task Force on Clinical Practice Guidelines and the Heart Failure Society of America. Circulation. 2017, 136:137-161. 10.1161/cir.0000000000000509

6. Moher D, Liberati A, Tetzlaff J, Altman DG, PRISMA Group: Preferred reporting items for systematic reviews and meta-analyses: the PRISMA statement. PLoS Med. 2009, 6:1000097. 10.1371/journal.pmed.1000097

7. Van Tassell BW, Trankle CR, Canada JM, et al.: IL-1 blockade in patients with heart failure with preserved ejection fraction. Circ Heart Fail. 2018, 11:005036. 10.1161/circheartfailure.118.005036

8. Redfield MM, Chen HH, Borlaug BA, et al.: Effect of phosphodiesterase- 5 inhibition on exercise capacity and clinical status in heart failure with preserved ejection fraction: a randomized clinical trial. JAMA. 2013, 309:1268-1277. 10.1001/jama.2013.2024

9. Borlaug BA, Melenovsky V, Koepp KE: Inhaled sodium nitrite improves rest and exercise hemodynamics in heart failure with preserved ejection fraction. Circ Res. 2016, 119:880-886. 10.1161/circresaha.116.309184

10. Borlaug BA, Anstrom KJ, Lewis GD, et al.: Effect of inorganic nitrite vs placebo on exercise capacity among patients with heart failure with preserved ejection fraction: the INDIE-HFpEF randomized clinical trial. JAMA. 2018, 320:1764-1773. 10.1001/jama.2018.14852

11. Nochioka K, Sakata Y, Miyata S, et al.: Prognostic impact of statin use in patients with heart failure and preserved ejection fraction. Circ J. 2015, 79:574-582. 10.1253/circj.CJ-14-0865

12. Abdul-Rahim AH, Shen L, Rush CJ, Jhund PS, Lees KR, McMurray JJ, VICCTA-Heart Failure Collaborators: Effect of digoxin in patients with heart failure and mid-range (borderline) left ventricular ejection fraction . Eur J Heart Fail. 2018, 20:1139-1145. 10.1002/ejhf.1160

13. Kosmala W, Holland DJ, Rojek A, Wright L, Przewlocka-Kosmala M, Marwick TH: Effect of If-channel inhibition on hemodynamic status and exercise tolerance in heart failure with preserved ejection fraction: a randomized trial. J Am Coll Cardiol. 2013, 62:1330-1338. 10.1016/j.jacc.2013.06.043

14. Maier LS, Layug B, Karwatowska-Prokopczuk E, et al.: RAnoLazIne for the treatment of diastolic heart failure in patients with preserved ejection fraction: the RALI-DHF proof-of-concept study. JACC Heart Fail. 2013, 1:115-122. 10.1016/j.jchf.2012.12.002

15. Zile MR, Bourge RC, Redfield MM, Zhou D, Baicu CF, Little WC: Randomized, double-blind, placebocontrolled study of sitaxsentan to improve impaired exercise tolerance in patients with heart failure and a preserved ejection fraction. JACC Heart Fail. 2014, 2:123-130. 10.1016/j.jchf.2013.12.002

16. Filippatos G, Teerlink JR, Farmakis D, et al.: Serelaxin in acute heart failure patients with preserved left ventricular ejection fraction: results from the RELAX-AHF trial. Eur Heart J. 2014, 35:1041-1050. 10.1093/eurheartj/eht497

17. Solomon SD, McMurray JJV, Anand IS, et al.: Angiotensin-neprilysin inhibition in heart failure with preserved ejection fraction. N Engl J Med. 2019, 381:1609-1620. 10.1056/NEJMoa1908655

18. Pfeffer MA, Claggett B, Assmann SF, et al.: Regional variation in patients and outcomes in the Treatment of Preserved Cardiac Function Heart Failure With an Aldosterone Antagonist (TOPCAT) trial. Circulation. 2015, 131:34-42. 10.1161/circulationaha.114.013255

19. Edelmann F, Wachter R, Schmidt AG, et al.: Effect of spironolactone on diastolic function and exercise capacity in patients with heart failure with preserved ejection fraction: the Aldo-DHF randomized controlled trial. JAMA. 2013, 309:781-791. 10.1001/jama.2013.905

20. Mancini DM, Eisen H, Kussmaul W, Mull R, Edmunds LH Jr, Wilson JR: Value of peak exercise oxygen consumption for optimal timing of cardiac transplantation in ambulatory patients with heart failure. Circulation. 1991, 83:778-786. 10.1161/01.cir.83.3.778

21. Baral N, Changezi HU, Khan MR, et al.: Inspiratory muscle training in patients with heart failure with preserved ejection fraction: a meta-analysis. Cureus. 2020, 12:12260. 10.7759/cureus.12260

22. Pitt B, Pfeffer MA, Assmann SF, et al.: Spironolactone for heart failure with preserved ejection fraction . N Engl J Med. 2014, 370:1383-1392. 10.1056/NEJMoa1313731

23. Alehagen U, Benson L, Edner M, Dahlström U, Lund LH: Association between use of statins and mortality in patients with heart failure and ejection fraction of $\geqslant 50$. Circ Heart Fail. 2015, 8:862-870. 10.1161/CIRCHEARTFAILURE.115.002143 


\section{Cureus}

24. Eggebeen J, Kim-Shapiro DB, Haykowsky M, et al.: Dosing with beetroot juice improves submaximal endurance and blood pressure in older patients with heart failure and preserved ejection fraction. JACC Heart Fail. 2016, 4:428-437. 10.1016/j.jchf.2015.12.013 